Bangladesh J. Plant Taxon. 25(2): 209-214, 2018 (December)

(C) 2018 Bangladesh Association of Plant Taxonomists

\title{
INCLUSION OF KICKXIA ABHAICA D.A. SUTTON IN THE GENUS NANORRHINUM (PLANTAGINACEAE): EVIDENCE FROM ITS NUCLEAR RIBOSOMAL DNA SEQUENCES
}

\author{
M. Ajmal Ali ${ }^{1}$ \\ Department of Botany and Microbiology, College of Science, King Saud University, \\ Riyadh-11451, Saudi Arabia
}

Keywords: Kickxia abhaica; Antirrhineae; Nanorrhinum abhaicum; ITS; nrDNA; Saudi Arabia.

\begin{abstract}
The nuclear ribosomal DNA (nrDNA) internal transcribed spacers (ITS) sequences is extensively used in the plant molecular phylogenetics for plant taxonomic identification and DNA barcoding purposes because the nrDNA ITS gene is easy to amplify by using the universal primers, its length is shorter and thus easy to sequence, and has strong discrimination power to distinguish the taxon at the species level. The present molecular phylogenetic analysis of ITS nrDNA sequences focuses to determine the taxonomic status of an unresolved endemic taxon Kickxia abhaica D.A. Sutton (Family Plantaginaceae, tribe Antirrhineae) reported from Saudi Arabia. The analysis supports the transfer of $K$. abhaica under the genus Nanorrhinum.
\end{abstract}

\section{Introduction}

The tribe Antirrhineae which comprises ca. 30 genera (Sutton, 1988) has undergone several taxonomic changes during last two decades. The genus Kickxia Dumort. (Family Plantaginaceae, tribe Antirrhineae) comprises ca. 25 accepted species (APG III, 2009). Based on the mode of dehiscence of capsule, the genus Kickxia has been divided into sections i.e. Kickxia sect. Kickxia and Kickxia sect. Valvatae (Sutton, 1988). The sections Kickxia sect. Kickxia and Kickxia sect. Valvatae were raised to the rank of subgenera (Smith, 1973). The species with valvate capsules were treated under Pogonorrhinum and Nanorrhinum (Betsche, 1984). Ghebrehiwet (2001) considered Kickxia and Nanorrhinum as two distinct genera on the basis of morphological analysis. The molecular phylogeny of mediterranean genera Chaenorhinum, Kickxia and Nanorrhinum based on nrDNA ITS and rpl32-trnL sequence data also supports the recognition of the clade comprising Kickxia sect. Valvatae as Nanorrhinum; as a result, new combinations i.e. Nanorrhinum petranum (Danin) Yousefi \& Zarre, Nanorrhinum judaicum (Danin) Yousefi \& Zarre and Nanorrhinum scariosepalum (Tackh. \& Boulos) Yousefi \& Zarre were established from Kickxia petrana Danin, Kickxia judaica Danin and Kickxia scariosepala Tackh. \& Boulos, respectively (Yousefi et al., 2016).

The genus Kickxia in Saudi Arabia is represented by nine species and one subspecies [Kickxia abhaica D.A. Sutton, K. acerbiana (Boiss.) Tackh. \& Boulos, K. aegyptiaca (L.) Nab., $K$. collenetteana D.A. Sutton, K. corallicola D.A. Sutton, K. elatine subsp. crinita Greuter, K. hastata (R.Br. ex Benth.) Dandy, K. petiolata D.A. Sutton, K. pseudoscoparia V.W. Smith and K. scalarum D.A. Sutton] described under the family Scrophulariaceae (Chaudhary, 2001), out of which the taxonomic status of $K$. abhaica D.A. Sutton, K. acerbiana (Boiss.) Tackh. \& Boulos and $K$. hastata (R.Br. ex Benth.) Dandy is still unresolved (http://www.theplantlist.org/), $K$. abhaica D.A. Sutton [Rev. Antirrhinea: 241 (1988). Plate Scroph. 17.] have been reported as

${ }^{1}$ E-mail: ajmalpdrc@gmail.com 
endemic to Saudi Arabia (Chaudhary, 2001). The present study aims to resolve the taxonomic status of the K. abhaica based on the molecular phylogenetic analysis of ITS nrDNA sequences.

\section{Materials and Methods}

Collection of the leaf material of Kickxia abhaica:

The leaf material of $K$. abhaica was collected from the specimen [Dharb-Abha Road, 5-41982, S. Chaudhary 3907 (KSUH)] deposited at the Herbarium (Department of Botany and Microbiology, College of Science, King Saud University, Riyadh, Saudi Arabia). A total of 16 species of Kickxia was employed in this study (Table 1). The taxonomic identification of the herbarium specimens were reconfirmed with the taxonomic description mentioned in recent Flora of the Kingdom of Saudi Arabia (Chaudhary, 2001).

Table 1. The GenBank accessions of the ingroup and outgroup taxon included in the molecular phylogenetic analysis of Kickxia abhaica.

\begin{tabular}{|c|c|c|}
\hline & Taxon & GenBank Acc. No. \\
\hline \multicolumn{3}{|c|}{ Ingroup } \\
\hline 1. & Nanorrhinum cabulicum (Benth.) Podlech \& Iranshahr & KT031916 \\
\hline 2. & Kickxia sagittata (Poir.) Rothm. & KT031902 \\
\hline 3. & K. scoparia (Brouss. ex Spreng.) G.Kunkel \& Sunding & KT031903 \\
\hline 4. & K. urbanii (Pit.) K.Larsen & KT031915 \\
\hline 5. & K. scariosepala Täckh. \& Boulos & KT031911 \\
\hline 6. & K. macilenta (Decne.) Danin & KT031908 \\
\hline 7. & K. petrana Danin & KT031909 \\
\hline 8. & K. judaica Danin & KT031907 \\
\hline 9. & Kickxia lanigera (Desf.) Hand.-Mazz. & KX061033 \\
\hline 10. & K. spuria (L.) Dumort. & KT031914 \\
\hline 11. & K. sieberi (Rchb.) Dörfl. \& Allan & KT031912 \\
\hline 12. & K. cirrhosa (L.) Fritsch & KT031896 \\
\hline 13. & K. aegyptiaca (L.) Nab. & KT031905 \\
\hline 14. & K. elatine (L.) Dumort. & KT031898 \\
\hline 15. & K. commutate (Bernh. ex Rchb.) Fritsch & KT031897 \\
\hline \multirow[t]{2}{*}{16.} & K. abhaica D.A. Sutton & MH628533 \\
\hline & [= Nanorrhinum abhaicum (D.A. Sutton) Ajmal Ali comb. nov.] & \\
\hline \multicolumn{3}{|c|}{ Outgroup } \\
\hline 17. & Anarrhinum bellidifolium (L.) Willd. & AY878116 \\
\hline
\end{tabular}

Extraction of genomic DNA, amplification and sequencing of nrDNA ITS gene:

The leaf material was crushed with liquid nitrogen using 'Qiagen Tissue Lyser' (\# 85300). The robotic workstation 'QIAcube' (\# 9001292) using 'DNeasy Plant Mini Kit' (\# 69104) was used for automated purification of the total genomic DNA. The nuclear ribosomal DNA ITS sequences (ITS1-5.8S and ITS2) were amplified in the thermal cycler (Applied Biosystems Veriti) via polymerase chain reaction using the primers (White et al., 1990) [forward primer ITS1 (5' GTCCACTGAACCTTATCATTTAG3') and the reverse primer ITS4 (5'TCCTCCGCTTATT GATATGC3')] and PCR Mix (\# K-2011, Bioneer, Daejeon, Republic of Korea). The DNA sequencing of the amplified product was performed using kit (\# 4337455, BigDye Terminator 
cycle sequencing kit, Perkin-Elmer, Applied Biosystems) in DNA Analyzer (Perkin- Elmer, Applied Biosystems, \# ABI PRISM 3730XL).

Molecular phylogenetic analysis of the nrDNA ITS gene sequences:

The nrDNA ITS sequences of a total number of 16 species of Kickxia s.s. and s.l. and outgroup sequence (Table 1) were retrieved from NCBI GenBank. The ITS sequences of nrDNA of Anarrhinum bellidifolium (GenBank accession No. AY878116) was used as outgroup in the molecular phylogenetic analysis because the genus Anarrhinum shows close relationships to the genus Kickxia (Yousefi et al., 2016). The alignment software 'CLUSTAL X v.1.81' (Thompson et al., 1997) was used to align the FASTA format DNA sequences. The parsimony (maximum parsimony, MP) (Nei and Kumar, 2000; Eck and Dayhoff, 1996) analysis using bootstrap method (Felsenstein, 1985) and maximum likelihood (ML) analysis using maximum composite likelihood method (Tamura et al., 2004) were used to conduct the molecular phylogenetic analyses using the molecular phylogenetic analysis software MEGA X (Kumar et al., 2018).

\section{Results and Discussion}

The aligned nrDNA ITS data (ITS1, 5.8S, and ITS2 region) matrix was 622 bp (base pair) long. The most parsimonious tree out of nine parsimonious trees (length $=84$ ) showed consistency index (CI) 0.781 and retention index (RI) 0.932. The ITS region (ITS1-5.8S-ITS2) of $K$. abhaica possessed 613 bp [ITS1: 228 bp, GC content 69\%; 5.8S: 164 bp, GC content 54\%; ITS2: 221 bp, GC content $71 \%]$.

The present molecular phylogenetic analysis of nrDNA ITS sequences revealed that Kickxia s.l. is monophyletic and sister to Kickxia s.s. The maximum parsimony phylogenetic tree (Fig. 1) showed two main clades i.e. Kickxia s.s. clade (BS 96\%) and Nonorrhinum clade (BS 100\%). K. abhaica nested within the Kickxia s.l./Nonorrhinum clade (BS 90\%). The Kickxia s.l. (K. scoparia - K. urbani - K. sagittata) clade forms a distinct group (BS 90\%). The ML tree with the highest log likelihood (-1294.69) recovered phylogenetic tree topology similar to MPT (Fig 1).

The tribe Antirrhineae (under Scrophulariaceae s.l.), with c. 300 species distributed in c. 30 genera constitutes a major clades of Plantaginaceae (Albach et al., 2005). The member of the tribe Antirrhineae are characterized by their herbaceous habit; two-lipped tubular corolla, 3-lobed lower lip and 2-lobed upper lip, gibbose, sometimes spurred at the base; 5 epipetalous stamens out of which 2 or 4 fertile, 2-carpelled fruits, operculate / valvate capsules (Sutton, 1988), and unique antirrhinosides / iridoid glycosides (Beninger et al., 2008). The systematic position of both the tribe and genera of the tribe Antirrhineae has been much debated (Ghebrehiwet et al., 2000), and the generic limits is still unresolved especially in the case of the genera Chaenorhinum, Kickxia and Nanorrhinum (Ghebrehiwet et al., 2000; Albach et al., 2005).

The morphological characteristics of taxon at lower level vary under different geographical and environmental condition; hence, requires sufficient taxonomic expertise for taxon identification based on morphology. In contrast, the DNA sequences have least or hardly influence by the geographical or environmental condition, and even remain unchanged during the developmental stages; therefore, the DNA barcode sequence such as ITS, ycf5, $r b c \mathrm{~L}, m a t \mathrm{~K}$, $r p o \mathrm{C} 1, p s b \mathrm{~A}-t r n \mathrm{H}, n d h \mathrm{~F}, \operatorname{trn} \mathrm{L}-\mathrm{F}$, and $r p s 16$ based species identification together with morphological features gaining wide acceptance recently (Marcon et al., 2005; Liu et al., 2011; Rai et al., 2012; Ali et al., 2014). The ML tree showed two main clades i.e. Kickxia s.s. clade (BS 99\%) and Nonorrhinum clade (BS 100\%). K. abhaica nested within the Kickxia s.l./Nonorrhinum Clade (BS 71\%), the Kickxia s.l. (K. sagittata- K. scoparia-K. urbani) clade forms a distinct group (BS 90\%). Previously, K. scoparia, K. urbani and K. sagittata were recognized as Nanorrhinum 


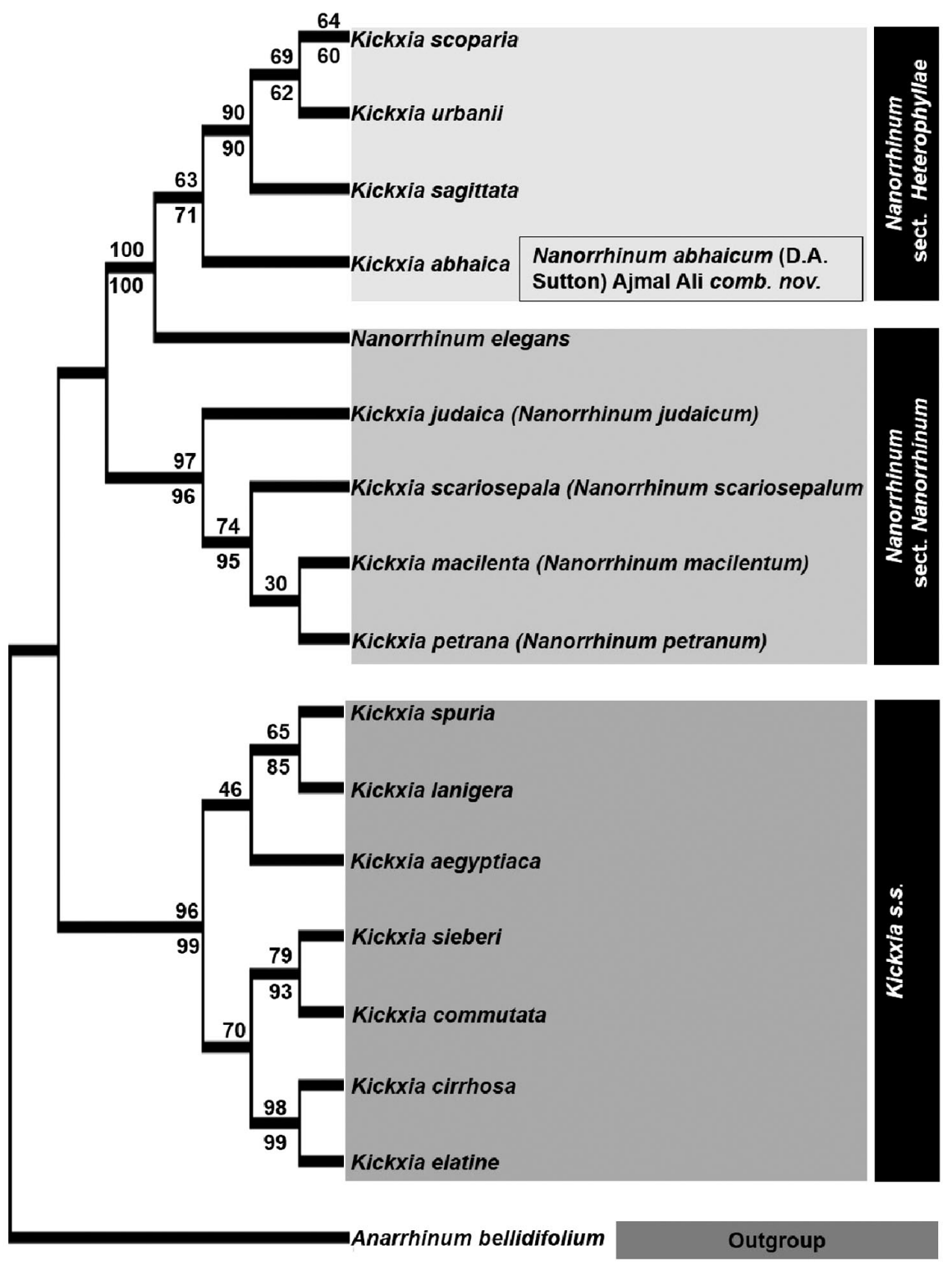

Fig. 1. The phylogenetic tree showing the systematic position of Kickxia abhaica $[=$ Nanorrhinum abhaicum (D.A. Sutton) Ajmal Ali comb. nov.]. The phylogenetic analysis (1000 bootstrap replicates) was inferred using the Maximum Parsimony method. The numbers at the nodes are the bootstrap supports in MP (above) and ML (below) analysis.

(Smith, 1973) under the sect. Heterophyllae (Yousefi et al., 2016) or as Pogonorrhinum (Betsche, 1984). The taxonomic status of $K$. collenetteana (branches prostrate spreading, rigid, leafy; leaves all elliptic to oblong), $K$. corallicola (branches flexuous, tangled; petiole long, capillary, twining), $K$. hastata (annual delicate herb), K. petiolata (leaves homomorphic, without any basal lobe; petioles becoming thickened woody; spur coming out from corolla base) and $K$. scalarum (petioles 
prominent capillary, often twining; corolla drying dark) reported from Saudi Arabia are unresolved, and its DNA sequence for any gene are not available in the GenBank. Therefore, the DNA sequencing of these taxon are required to know its taxonomic status within the tribe Antirrhineae. Moreover, the molecular phylogenetic analysis of nrDNA ITS sequence of $K$. abhaica [which was described as endemic to Saudi Arabia (Chaudhary, 2000)] supports its transfer to the genus Nanorrhinum, and thus the proposed new combinations in Nanorrhinum (new generic record for Saudi Arabia) is as follows.

\section{New combination in Nanorrhinum}

Nanorrhinum abhaicum (D.A. Sutton) Ajmal Ali, comb. nov.

Basionym: Kickxia abhaica D.A. Sutton [Rev. Antirrhinea: 241 (1988). Plate Scroph. 17.]

\section{Acknowledgement}

Research supported by the King Saud University, Deanship of Scientific Research, College of Science, Research Center.

\section{References}

Albach, D.C., Meudt, H.M. and Oxelman, B. 2005. Piecing together the 'new' Plantaginaceae. Am. J. Bot. 92: 297-315.

Ali, M.A., Gábor, G., Norbert, H., Balázs, K., Al-Hemaid, F.M.A., Pandey, A.K. and Lee, J. 2014. The changing epitome of species identification - DNA barcoding. Saudi J. Biol. Sci. 21(3): 204-231.

APG III (Angiosperm Phylogeny Group). 2009. An update of the Angiosperm Phylogeny Group classification for the orders and families of flowering plants: APG III. Bot. J. Linn. Soc. 161: 105-121.

Beninger, C.W., Cloutier, R.R. and Grodzinski, B. 2008. The iridoid glucoside, antirrhinoside from Antirrhinum majus L. has differential effects on two generalist insect herbivores. J. Chem. Ecol. 34: 591-600.

Betsche, L. 1984. Taxonomische Untersuchungen an Kickxia Dumortier (s.1.). Die neuen Gattungen Pogonorrhinum n. gen. und Nanorrhinum n. gen. Cour. Forsch. Inst. 71: 125-142.

Chaudhary, S. (Ed.) 2001. Flora of the Kingdom of Saudi Arabia. Ministry of Agriculture and Water, National Herbarium, National Agriculture and Water Research Center, Riyadh, Saudi Arabia, Vol. II(2), pp. 435-439.

Eck, R.V. and Dayhoff, M.O. 1966. Atlas of Protein Sequence and Structure. National Biomedical Research Foundation, Silver Springs, Maryland, USA.

Felsenstein, J. 1985. Confidence limits on phylogenies: An approach using the bootstrap. Evolution 39: 783791.

Ghebrehiwet, M. 2001. Taxonomy, phylogeny and biogeography of Kickxia and Nanorrhinum (Scrophulariaceae). Nordic J. Bot. 20: 655-690.

Kumar, S., Stecher, G., Li, M., Knyaz, C. and Tamura, K. 2018. MEGA X: Molecular Evolutionary Genetics Analysis across computing platforms. Mol. Biol. Evol. 35: 1547-1549.

Liu, C., Liang, D., Gao, T., Pang, X., Song, J., Yao, H., Han, J., Liu, Z., Guan, X., Jiang, K., Li, H. and Chen, S. 2011. PTIGS-IdIt, a system for species identification by DNA sequences of the $p s b \mathrm{~A}-\operatorname{trn} \mathrm{H}$ intergenic spacer region. BMC Bioinformatics 12: S4.

Marcon, A.B., Barros, I.C. and Guerra, M. 2005. Variation in chromosome numbers, CMA bands and 45S rDNA sites in species of Selaginella (Pteridophyta). Ann. Bot. 95: 271-276.

Nei, M. and Kumar, S. 2000. Molecular Evolution and Phylogenetics. Oxford University Press, New York. 
Rai, P.S., Bellampalli, R., Dobriyal, R.M., Agarwal, A., Satyamoorthy, K. and Narayana, D.A. 2012. DNA barcoding of authentic and substitute samples of herb of the family Asparagaceae and Asclepiadaceae based on the ITS2 region. J. Ayurveda Integr. Med. 3: 136-140.

Smith, V.A. 1973. A revision of the genus Kickxia with particular reference to the section Heterophyllae in the Canary Islands. M. Sc. thesis, University of Reading, UK.

Sutton, D.A. 1988. A revision of the tribe Antirrhineae. Oxford Univ. Press.

Tamura, K., Nei, M. and Kumar, S. 2004. Prospects for inferring very large phylogenies by using the neighbor-joining method. Proc. Nat. Acad. Sci. (USA) 101: 11030-11035.

Thompson, J.D., Gibson, T.J., Plewniak, F., Jeanmougin, F. and Higgins, D.G. 1997. The CLUSTAL_X windows interface: Flexible strategies for multiple sequence alignment aided by quality analysis tools. Nucleic Acids Res. 24: 4876-4882.

Yousefi, N., Zarre, S. and Heubl, G. 2016. Molecular phylogeny of the mainly Mediterranean genera Chaenorhinum, Kickxia and Nanorrhinum (Plantaginaceae, tribe Antirrhineae), with focus on taxa in the Flora Iranica region. Nordic J. Bot. 34: 455-463.

(Manuscript received on 27 May 2018; revised on 26 September 2018) 